\title{
A NEW BOOK ON STALINISM BY J. ARCH GETTY
}

\author{
Aaron T. Hale-Dorrell \\ University of North Carolina \\ at Chapel Hill
}

\author{
Аарон Т. Хэйц-Дорремц \\ Университет \\ Северной Каролины \\ в Чапел-Хим
}

Abstract. The author reviews the latest monograph by J. Arch Getty, Professor of History at the University of California at Los Angeles, which offers a new installment in his long running inquiry into the practices of repression and power under Josef Stalin.

Keywords: USSR, Stalinism, J. Arch Getty.

E-mail: ahaledor[at]email.unc.edu

Copyright: (c) 2015 Hale-Dorrell. This is an open-access publication distributed under the terms of the Creative Commons Attribution License, which permits unrestricted use, distribution, and reproduction in any medium, provided the original author and source, the Tractus Aevorum journal, are credited.

Удк 94(47+57)|19|

\section{НОВАЯ МОНОГРАФИЯ ДЖ. А. ГЕТТИ О СТАЯИНИЗМЕ}

Аннотация. Автор анализирует вышедшую в 2013 г. монографию профессора истории Калифорнийского университета (Аос-Анжелес) Дж. А. Гетти, в которой представцены новые результаты исследований в рамках многолетних изысканий историка в области советских репрессивных практик и властных отношений при И. В. Сталине.

Ключевые слова: СССР, сталинизм, Дж. А. Гетти.

J. Arch Getty, Practicing Stalinism: Bolsheviks, Boyars, and the Persistence of Tradition (New Haven, CT: Yale University Press, 2013), Hardcover, 384 pp., $\$ 45.00$.

In interpreting the inner workings of Soviet power, Arch Getty's latest monograph, Practicing Stalinism, holds that personalized loyalties and patrimonial relationships defined politics. It challenges historians to privilege practices, enmities among leading figures, and the systemic nature of patronage. At the same time, it provocatively argues that Russian "political culture" contains deep continuities. 
Professor of History at the University of California at Los Angeles, Getty offers a new installment in his long running inquiry into the practices of repression and power under Josef Stalin. The book's eight chapters explore how determined men seized authority, how political pageantry legitimized power, and how leaders mastered patronage networks. The work progresses in roughly chronological order from the end of the Russian Civil War through the Great Terror, conveying how the party's top echelons operated in each period. Each chapter freely draws on sources housed in the Moscow archives, especially those of the Central Committee of the Communist Party. This empirical richness reflects the decades Getty has spent researching in these archives and publishing on the era. Characterizing the Orgburo, the Secretariat, and other bodies acting alongside the Politburo, these details provide the reader a glimpse inside the Central Committee's headquarters.

In addition, Getty uses the Party archives' records of guberniia and oblast party meetings to shed light on how networks permeated local outposts of party power. Practices common to many eras come into focus: top officials had the final say in decisions large and small. Authoritative figures from Moscow refereed local clan disputes. "Family circles" and "tails" followed powerful figures when they moved from one post to another. Central authorities struggled to get dissembling local bosses in line. In sum, formal structures mattered less than the personal relationships between actors. On this point, the book draws on the French theorist Pierre Bourdieu, who viewed practices as the real scene of the action. State structures that we perceive by studying neatly archived files, Bourdieu held, are only an outward manifestation of hidden networks (292).

Scholars have highlighted the personalized side of Russian politics for many years. Take, for instance, David Ransel's study of the patronage network headed by Count N. I. Panin in the eighteenth century. ${ }^{1}$ With the benefit of access to the archives, historians have begun to scrutinize the relationships built into elite politics from the 1920 s to the $1960 \mathrm{~s}^{2} \mathrm{O}$. V. Khlevniuk has maintained that a party oligarchy comprised of Stalin and his followers formed by 1935, after which Stalin consolidated his total dominance. Under those conditions, conflicts among individuals resulted from their positions as representatives of various institutional interests. ${ }^{3}$

Stepping into this line of inquiry, Practicing Stalinism offers an analytical framework for politics that is sweeping in scale. Stalin's coterie fought among themselves and power concentrated in a narrowing circle, but not because of Bolshevik ideology or Stalin's character. Instead, these and many other phenomena resulted from a political culture ingrained in

\footnotetext{
${ }^{1}$ Ransel 1975.

${ }^{2}$ Gorlizki and Khlevniuk 2004; Sushkov 2009.

${ }^{3}$ Khlevniuk 2009, xvi-xix.
} 
Russia many centuries before 1917 . Historians have set aside the totalitarian model and its insistence on the monolithic unity of the Communist Party. Yet scholars have retained its emphases on ideology and the fundamentally modern nature of the Bolshevik project (19). By contrast, Practicing Stalinism stresses deep continuities. Taking Tsar Ivan IV as a decisive figure in its comparison, the book likens the conditions facing rulers in the early modern period to those confronting Soviet leaders centuries later. Each had to govern a vast territory, a fractious elite, and a restive peasant majority. Similarities between the practices of Ivan's reign and those of Stalin's rule are evidence of more than comparable reactions to equivalent circumstances. Downplaying a functionalist explanation, Getty writes, "The strength of these continuities ... suggests that there is something deeper here" (17).

As a unified but evolving set of practices, political culture provides that deeper link. Developing in response to a necessity, each practice persisted even once that problem subsided. As a storehouse of practices, political culture allowed new leaders to confront new challenges using methods readily available without even having to consciously choose. Enduring to the present, patrimonialism and related practices have survived war, revolution, ideological ruptures, modernization, urbanization, and the advent of pass politics. This stress on continuity puts the argument at odds with neotraditionalist understandings, which posit that apparently archaic practices only recreated older forms, while in fact constituting modern approaches suited to the needs of an industrial society. ${ }^{4}$

To establish its framework, Practicing Stalinism challenges Max Weber's dichotomy between premodern patrimonial systems and their natural successors: rational bureaucratic states. The introduction maintains that these two forms in fact coexisted in the Soviet case $(4,7,20)$. Yet chapters 3 and 4 toy with a similar dichotomy. "Upstairs at the Central Committee," leading figures favored patrimonial authority and defended the right to intervene in decisions both large and small. In contrast, their subordinates "downstairs" favored bureaucratic regularity (146). These two principles did not coexist because the "boyars" and their patrimonial authority held sway. Still, this schema seems at odds with the chaotic reality observed in chapters 6,7 , and 8 . Even intervention from the top could not always settle conflict. Stalin's "leading group" tried to control the clans in the oblasts, who often exhibited "localism" and asserted relative autonomy from Moscow. After several frustrated efforts to rein them in, Stalin unleashed the Great Terror that decapitated the local networks, making local party bosses and their clients one of many groups of victims. Only two of seventy-one heads of major party organizations survived: L. P. Beria and N. S. Khrushchev, each a loyal member of Stalin's own clan (263). Even such a bloodletting secured only a brief respite from the squabbling.

\footnotetext{
${ }^{4}$ Martin 2000, 161-82; and Hoffmann 2003.
} 
Readers should consider at face value the caveats offered in Practicing Stalinism. As the introduction concedes, some Soviet practices emerged from ideological dictums or from responses to unique circumstances. Holding on to existing forms, Russia's new masters adopted elements of Orthodox imagery for their political theater. At the same time, they vehemently denounced the Orthodox Church for ideological reasons. As Getty concludes, "it would be ... improbable to imagine the Stalinists consciously picking and choosing from a menu of traditional practices" (65). A similar note of caution emphasizes the limits of historical parallels. Old Bolsheviks only functionally acted as "knights of the revolution," jealous of their own independence and prerogatives. Bosses in industry and the party only metaphorically mirrored "grandees" and "boyars." These notes signal restraint, an effort to prevent the book from overplaying its hand in arguing for the persistence of tradition.

For all of its detail and its convincing account of the mechanics of politics, Practicing Stalinism gives itself a more difficult task in making the case for continuity in political culture. In privileging a centuries-long strand of practices at the expense of a functionalist alternative, the analysis often seems to push social context, ideology, and policy entirely into the shadows off stage. To illustrate, it accents apparent inheritances from the distant past while downplaying distinctive features of the Bolsheviks' experiences of revolution, civil war, and state building. The Old Bolsheviks' lineage in conspiratorial underground cells lingers in the wings, invisible, only to suddenly appear at center stage. Then we learn that, decades after the fact, Stalin's henchmen V. M. Molotov and L. M. Kaganovich each justified the Great Terror's destruction of the regional bosses on the grounds that the victims were Old Bolsheviks, steeped in the ways of secrecy and intrigue (264). How could they have not been guilty of plotting something? In another case, we are told that the Bolsheviks were "ideologues in their bones" (20), yet they engaged in sanguinary political combat on account of mere personal hostilities. Within Stalin's inner circle alone, such animosities pitted A. A. Zhdanov against G. M. Malenkov and G. K. (Sergo) Ordzhonikidze against V. M. Molotov (169).

Although particularly durable in Russia, personalized politics that both ensure a system can function and interfere with its regular operation are not distinctly Russian, nor do such practices mark the country as somehow "backward." Arguing for a patrimonial interpretation of Kremlin politics in the era of President V. V. Putin, the epilogue acknowledges that patronage has characterized most systems at most times. As a parallel, it offers an example from United States' past: the "spoils system" that developed after the 1829 inauguration of President Andrew Jackson (289). This phenomenon has evolved and persisted. To wit, a New York Times frontpage article on February 15, 2015, the day I finished reading Practicing Stalinism, reported on Jeb Bush's efforts during the twelve years his father, George H. W. Bush, spent as vice-president and president (1981-93) 
to utilize connections within the administration to further interests in Republican Party politics and in business.

By challenging historians to consider the personal and practical side of politics alongside ideology and policy, Practicing Stalinism should stimulate debate among historians about how to approach political history. Responding by incorporating practice without excluding policy and ideology, historians of the 1920s and 1930s-and those exploring other eras of Russia's past-can create complex frameworks for balancing all three. By contributing to that tendency, Getty's work promises to advance scholarly inquiry and become a component of graduate seminars for years to come.

\section{References}

Gorlizki, Yoram, and Oleg V. Khlevniuk. 2004. Cold Peace: Stalin and the Soviet Ruling Circle, 1945-1953. New York: Oxford University Press.

Hoffmann, David L. 2003. Stalinist Values: The Cultural Norms of Soviet Modernity, 1917-1941. Ithaca, NY: Cornell University Press.

Khlevniuk, Oleg V. 2009. Master of the House: Stalin and His Inner Circle, trans. by Nora S. Favorov. New Haven, CT: Yale University Press.

Martin, Terry. 2000. "Modernization or Neo-traditionalism? Ascribed Nationality and Soviet Primordialism." In Russian Modernity: Politics, Knowledge, and Practices, ed. by David L. Hoffmann and Yanni Kotsonis, 161-82. New York: St. Martin's Press.

Ransel, David. 1975. The Politics of Catherinian Russia: The Panin Party. New Haven, CT: Yale University Press.

Sushkov, A. I. 2009. Prezidium TsK KPSS v 1957-1964: Lichnost' $i$ Vlast'. Ekaterinburg: Ural'skii tsentr akademicheskogo obsluzhivaniia. 